\title{
PENGARUH MODIFIKASI MAKANAN RONDO ROYAL TERHADAP EKSISTENSINYA DI MASYARAKAT MODERN
}

\author{
Mu'adz ${ }^{[1]}$ \\ Program studi Ilmu Teknologi Pangan \\ muadzblooods@gmail.com
}

\begin{abstract}
ABSTRAK
Indonesia merupakan bangsa yang melimpah akan keanekaragaman. Diantara sekian banyak keragaman yang ada di Indonesia, makanan tradisional berbasis pangan lokal merupakan salah satu keanekaragaman yang begitu menarik untuk dikupas dikarenakan terhimpitnya eksistensi makanan tradisional berbasis pangan lokal akibat modernisasi pangan dari budaya luar yang secara perlahan-lahan menghilangkan fungsi sosial makanan, representasi sosial budaya dalam mengkonsepkan makanan serta identitas kolektivitas yang seharusnya dapat dilestarikan melalui tradisi kuliner berbasis pangan lokal. Penelitian ini sangat penting untuk mengetahui apakah makanan rondo royal dapat diterima kembali di kalangan masyarakat modern seperti saat ini serta usaha apa saja yang perlu dilakukan untuk mempertahankan eksistensinya di tengah himpitan makanan modern. Dari usaha-usaha yang dilakukan tidak menutup kemungkinan untuk menjadikanya model bagi jenis makanan tradisional lainya untuk melebarkan sayapnya kembali ditengah keterpurukanya saat ini. Hasil penelitian menunjukkan bahwa kehadiran makanan tradisional rondo royal dengan modifikasnya dapat diterima di tengah-tengah makanan modern. Hal ini menunjukan dengan adanya suatu aktivitas yang menghasilkan suatu produk maupun ide sekaligus proses belajar merupakan cerminan dari kebudayaan.
\end{abstract}

Kata kunci : Rondo royal, Pangan lokal, Keanekaragaman

\section{ABSTRACT}

Indonesia is an abundant nation of diversity. Among the many diversity that exist in Indonesia, local food-based traditional food is one of the diversity that is so interesting to peel because of the existence of local food-based traditional food due to the modernization of food from outside cultures which slowly eliminates the social function of food, socio-cultural representation in conceptualizing food and collectivity identity that should be preserved through local food-based culinary traditions. This research is very important to know whether royal rondo food can be accepted again in modern society as it is now and what efforts need to be made to maintain its existence amid the crush of modern food. From the efforts made do not rule out the possibility to make it a model for other types of traditional food to spread its wings back amid the current adversity. The results showed that the presence of traditional rondo royal food with its modification was acceptable in the midst of modern food. This shows with the existence of an activity that produces a product or idea as well as the learning process is a reflection of culture.

Keywords: Rondo royal, Local food, Diversity

\section{PENDAHULUAN}

Salah satu kebutuhan pokok manusia dalam melangsungkan kehidupan adalah pangan atau lebih umum dikenal dengan nama makanan. Definisi mengenai makanan juga dijelaskan dari berbagai sumber. Menurut Ria Andayani (2006, hlm. 120), bahan-bahan yang diperlukan tubuh supaya tetap hidup adalah 
makanan. Makna lain dari makanan juga diungkapkan oleh Nina Merlina (2006, hlm. 95-96) bahwa segala sesuatu yang berkhasiat bagi tubuh, dapat diminum dan dimakan baik itu berbagai jenis minuman ataupun makanan pokok, lauk-pauk, sayuran, penganan.

Makanan dapat mencirikan identitas suatu bangsa dari suatu daerah dan hal itu merupakan bagian dari produk kebudayaan (Yufiza, 2010, hlm. 145). Makanan tradisional merupakan makanan yang ditumbuhkembangkan di lingkungannya masing-masing yang penciptaan dan pengembanganya dilakukan oleh setiap kelompok manusia atau suku bangsa setempat (Ria Andayani S., 2006, hlm. 186). Makanan tradisional dapat menjadi cerminan budaya dikarenakan keberadaan atau eksistensi makanan tradisional umumnya tidak terlepas dari adat istiadat masyarakat setempat (Noviadji, 2014, hlm.10).

Pembelajaran mengenai makanan dalam konteks budaya mengacu pada perilaku konkret masyarakat serta persoalan-persoalan yang praktis. Kecenderungan dalam menilai selera budaya makan orang lain tanpa disadari telah terbentuk dalam pergaulan antar suku bangsa secara stereotip. Tidak hanya stereotip budaya makan tradisional tetapi juga modern (Hidayah, 2010, hlm. 8).

Demikian pula dengan berjalanya waktu dan akrabnya modernisasi dengan kehidupan sehari-hari tidak dapat dipungkiri makanan dengan sifat modern lah yang kemudian mengambil alih peran makanan tradisional. Orientasi jenis makanan yang diproduksi ini memiliki kecenderungan ke arah Timur nonIndonesia dan Barat (makanan internasional). Ciri-ciri dari jenis makananya sendiri antara lain pembuatannya dengan menggunakan alat-alat yang canggih dan bahan yang digunakan serba buatan pabrik serta nama makanan yang menggunakan istilah asing (Yufiza, 2010, hlm. 145).

Oleh karena itu, diperlukan modifikasi makanan tradisional untuk meminimalisir hal-hal tersebut serta meningkatkan kualitasnya agar mampu bersaing dalam mempertahankan eksistensinya di tengah tengah gejolak makanan modern. Dalam memodifikasi suatu produk diperlukan juga sebuah inovasi atau ide yang menarik supaya target yang dituju bisa tercapai. Modifikasi makanan tradisional yang akan dibahas kali ini adalah makanan khas dari jepara yaitu rondo royal atau sering disebut dengan monyos yang berasal dari olahan bahan 
pangan fermentasi tradisional indonesia yaitu tape singkong (Barus dan Wijaya, 2011, hlm. 357). Proses fermentasi pada produk tape singkong dilakukan dengan bantuan mikroorganisme yang sering disebut dengan ragi, dimana ragi ini akan merombak zat pati pada singkong menjadi bentuk gula sederhana (Hasanah et al., 2013, hlm. 69).

Produk fermentasi sendiri memiliki beberapa keunggulan yaitu dari segi cita rasa, kemudahan dalam mencerna produk dan yang tidak kalah penting adalah kandungan nutrisi yang dibawa (Parwiroharsono, 2007, hlm. 88-89). Sebagai produk fermentasi, tape singkong memiliki berbagai macam nutrisi serta manfaat bagi tubuh diantaranya peningkatan kandungan vitamin B12 (Tiamina) oleh mikroorganisme yang berperan dalam proses fermentasi tape singkong, dimana vitamin ini memiliki manfaat memperbaiki fungsi otot dan syaraf serta mencegah terjadinya anemia. Selain itu pada 100 gram bahan terkandung protein sebesar 0,5 gram. Tape singkong sendiri digolongkan sebagai sumber probiotik sehingga mampu memperlancar saluran pencernaan (Nuraida dan Owens, 2014, hlm. 59).

Dengan adanya modifikasi makanan rondo royal sebagai sebagai produk pangan derivatif dari tape singkong yang memiliki keragaman nutrisi serta manfaat diharapkan mampu mendongkrak eksistensinya di tengah-tengah trend makanan modern saat ini.

\section{METODE PENELITIAN}

Penelitian dilakukan dengan metode deskriptif melalui pendekatan kualitatif. Maknanya peneliti memanfaatkan berbagai metode alamiah dalam memahami fenomena tentang apa yang dialami oleh objek penelitian dan akan dibahas atau digambarkan sesuai keadaan yang ada tanpa mengambil kesimpulan secara umum (Saebani, 2012, hlm. 66).

Tahapan penelitian yang dilakukan dalam modifikasi makanan rondo royal yaitu dengan mengganti menu makanan tradisional ini dengan berbagai macam nama dengan variasi isi dan topping. Cluster pertama ada "The royal widow" dengan modifikasi isian keju mozzarella dan topping keju parut dengan lumuran susu vanilla, Selanjutnya cluster kedua ada "janda mewah" dengan modifikasi isian matcha ditaburi parutan coklat bar rasa green tea dan yang ketiga dengan 
nama aslinya yaitu "rondo royal" sebagai menu atas dengan modifikasi isian coklat ditaburi meses coklat dengan balutan susu coklat.

\section{HASIL DAN PEMBAHASAN}
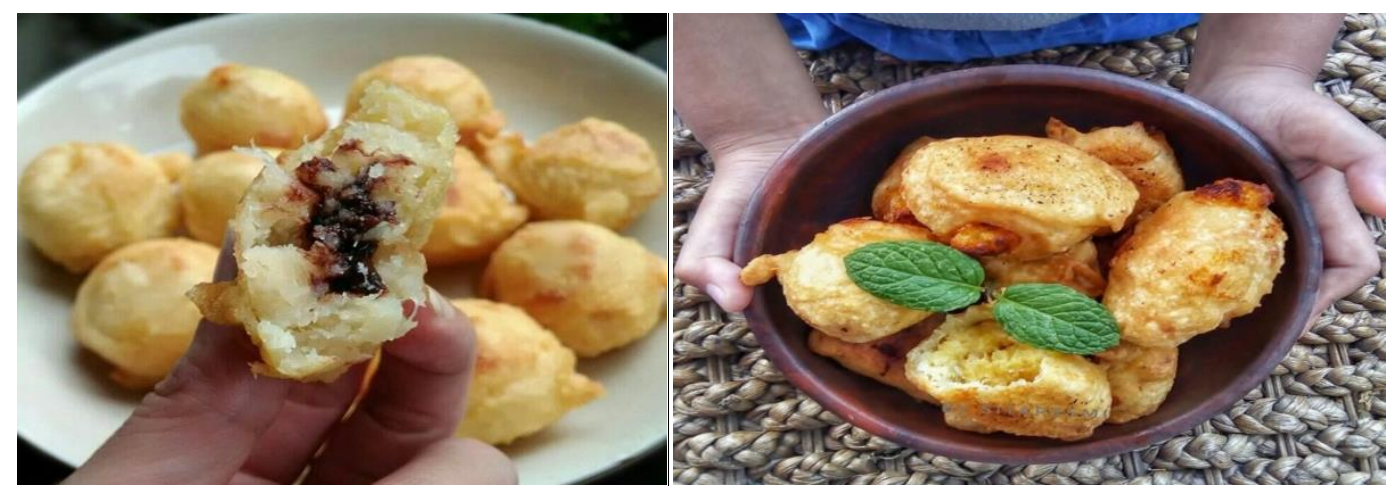

Gambar 1. Rondo royal modifikasi Gambar 2. Rondo royal tanpa modifikasi

Makanan rondo royal atau monyos merupakan makanan tradisional khas dari jepara. Rondo royal memiliki makna suatu makanan tradisional yang terbuat dari tape dengan bahan dasar tape singkong yang kemudian dihancurkan dan dibentuk sesuai selera masing-masing lalu dicelup ke dalam adonan tepung beras hingga merata dan digoreng. Kemudian makna dari penyebutan rondo royal sendiri tidak terlepas dari segi historisnya bahwa penamaan rondo royal bermula ketika zaman dahulu makanan ini pertama kali ditemukan oleh seorang janda yang kaya, karena dalam bahasa jawa rondo sendiri memiliki arti seorang janda dan royal sendiri berarti mewah.

Terlepas dari asal muasal penamaan rondo royal yang masih misteri, banyak pula dari masyarakat dahulu apabila mendengar makanan ini akan menimbulkan couriousity serta ingin mencoba untuk mencicipinya. Hal itu merupakan keunikan tersendiri bagi makanana tradisional rondo royal ini. Selain unik dari segi nama, makanan ini juga memiliki keunikan dari segi rasa dan tekstur dimana makanan ini mendapatkan rasa asam dan manis dari tape serta rasa asin dari tepung terigu, tekstur yang dibawa pun unik karena kriuk diluar serta lembut didalam yang memberikan sensasi tersendiri saat menikmatinya.

Dari keunikan-keunikan yang dibawa oleh makanan rondo royal, makanan tradisional ini tidak melupakan kandungan gizinya yang meliputi $30 \mathrm{ml}$ kalsium; 42,5\% karbohidrat; 56,1 gram air; 0,1 gram lemak dan protein. Berbagai macam kandungan gizi dalam makanan ini sangat berkhasiat dalam memperlancar sistem 
pencernaan, menyembuhkan bisul, menghilangkan jerawat serta mampu memperlancar menstruasi.

Dengan berbagai macam keunikan yang telah dibawa oleh makanan rondo royal sendiri ditambah dengan penambahan-penambahan isian serta topping dan modifikasi nama rondo royal sendiri membuat makanan ini tidak kalah eksis dari makanan-makanan modern yang sedang trend saat ini. Bahkan makanan ini juga telah merebak hingga menjamur ke dalam kawasan pusat perbelanjaan, mall, bahkan hingga masuk kedalam cofee bar. Hal tersebut menandakan bahwa dengan berbagai modifikasi, makanan ini bisa diterima di tengah-tengah masyarakat modern bahkan mamu menjadi primadona oleh kaum-kaum milenial.

\section{KESIMPULAN}

Terlepas dari stigma masyarakat yang berfikir hanya dapat menemukan makanan tradisional di pasar tradisional, ternyata dengan usaha-usaha yang dilakukan serta inovasi dan ide yang ada yaitu modifikasi dengan menjadikanya berbagai macam nama dengan makna yang sama serta penambahan isian dengan macam-macam topping pula, makanan tradisional ini dapat kembali dikenal masyarakat modern bahkan mampu menjadi primadona oleh kaum milenial.

\section{DAFTAR PUSTAKA}

Andayani, R.S.(2006). "Makanan Tradisional Masyarakat Betawi”, dalam Ani Rostiyati dan Toto Sucipto, Budaya Masyarakat Betawi, Bandung: Balai Kajian Sejarah dan Nilai Tradisional.

Barus, T dan Wijaya, L.N. (2011). Mikrobiota dominan dan perannya dalam cita rasa Tape singkong. Journal of Biota. 16(2): 354-361.

Hasanah, H., Jannah, A., \& Fasya, A.G. (2013). Pengaruh lama fermentasi terhadap kadar alkohol tape singkong (Manihot utilissima Pohl). Alchemy Journal of Chemistry. 2(1): 68-79

Hidayah, Z. (2010). Rasa dan Keanekaragaman Citra Rasa Nusantara. Makalah dalam Sarasehan Nasional Antropologi.

Khasanah, N., \& Wikandari, P.R. (2014). Pengaruh lama fermentasi dan penambahan bakteri asam laktat lactobacillus plantarum b1765 terhadap mutu produk tape singkong. Jurnal Mahasiswa Teknologi Pendidikan. 3(1): 78-84. 
Merlina, N.(2006). "Makanan Tradisional Masyarakat Banten”, dalam Adeng dan Sindu Galba. Sistem Teknologi Tradisional, Bandung: Balai Kajian Sejarah dan Nilai Tradisional.

Nuraida, L., \& Owens, J.D. (2014). Sweet, sour, alcoholic solid substrate fungal fermentations. Indigenous Fermented Foods of Southeast Asia. 137 (2): 56-66.

Noviadji, B.R.(2014).Desain Kemasan Tradisional Dalam Konteks Kekinian. Jurnal IKADO fakultas desai., 1(1); 10-21.

Parwiroharsono, S. (2007). Potensi pengembangan industri dan bioekonomi berbasis makanan fermentasi tradisional. Jurnal Ilmu Kefarmasian Indonesia. 5(2):85-91.

Saebani, B.A.(2012).Pengantar Antropologi. Bandung: CV Pustaka Setia.

Yufiza. (2010). Revitalisasi Makanan Lokal. Jurnal Jnana Budaya. 15(8); 139148. 